DOI: 10.35218/armca.2020.1.03

\title{
The Icon, a Hexadic Analysis
}

\section{Cristina Stratulat*}

\begin{abstract}
The present paper brings forward an analysis of the Orthodox icon, made by deploying the model of semi-logical hexade which describes the situation of creative communication. Starting with the presentation of the sociocultural context in which the icon appears and continuing with the other parameters of the hexade - the purpose which justifies the activation of the creative act, whom is this icon addressed, who created it, what psychological mechanisms have concurred to its birth and which is the result of this creative process - our focus has been the defining and description of what the icon is.
\end{abstract}

Keywords: icon, gift, semiotics, hexadic model.

Semiotics is considered a methodology which can be efficiently used by any scientific discipline ${ }^{1}$. This methodology supposes, briefly, three analytical horizons, that is: the structural analysis of the sign, the triadic analysis - syntactic, semantic, pragmatic - and situational analysis (of the generated situation of communication).

The structural analysis of the (macro)sign refers to the analysis of the relations between signifier and signified, form and content, expression and meaning, surface structure and deep structure etc.

Triadic analysis refers to an approach from three distinctive perspectives, that is: syntactic - of the relationship between signs, semantic of the relationship signified-referential (respectively signifier-referential, in the case of the relationship of motivation), and pragmatic - of the relationship between signified and signifier, on the one hand, between the sign and the interpreter, on the other hand.

Situational analysis (the hexadic model) supposes defining the "communication situation" (semiosis), through which one can find the answer to the series of questions of Harold Lasswell - who, what, whom, why and on what communication channel? - and to all these, one can add the sixth parameter - context - obtaining "an operational hexadic model"2. This analysis has as focus the optimization of communication and it is made of

\footnotetext{
* Lecturer Cristina Stratulat, PhD, "George Enescu" National University of Arts Iași.

${ }^{1}$ Traian D. Stănciulescu, La început a fost semnul ["At the beginning, it was he sign'],

"Performantica" Publishing House, Iaşi, 2004, p.217.

${ }^{2}$ Idem, p. 226.
} 
three steps: structural analysis, functional analysis and the elaboration of the optimizing model.

Structural analysis refers to the detailed research on the six structural parameters of the envisaged semiosis: the context in which communication takes place; the emitter, defined by personality factors (biological, psychological, social); the content of the transmitted message (the nature of the type of communication, the defining of content etc.); the used means of coding (the nature of the transmitted message - oral, written, drawn, sung etc., the type of language and the used channels, the blockings which can affect communication); the receiver of the message (the target group to which the message is addressed, the analysis of the personality of the receiver and the degree of orientation of the message); the purpose of the message (the intended purposes and effectively obtained goals).

Functional analysis supposes the establishment of some connections between the presented parameters, depending on the features of the communication situation itself.

The optimization phase refers to the modalities of stimulating the communication situation. It involves the evaluation of the efficiency and the attempt of optimizing each structural parameter, and also the entire redefining of the communication situation.

In the following pages, we will make an analysis of practical application of this method in order to attract the attention on this visual means of communication of the human being with God - the icon.

Just like the text, the icon is referential: it refers to another reality than that of the image itself, so that the reality targeted by the image is never instituted by it.

The term has its origins in the Greek term slkov whose meanings are: image, portrait, image reflected in a mirror, phantom, image of the spirit, resemblance, similarity, the most used being the one of "analogical imprinting of the shape" ${ }^{3}$.

The basis of the Christian icon can be found in the dogma of the Incarnation of the Son of God through which "The unseen has become seen, while the non-representable - represented. Now He addresses people only through words and the conveyance of the prophets. He shows Himself in the Person of the Embodied Word"4.

\footnotetext{
${ }^{3}$ Dan Chiţoiu, Repere în filosofia bizantină [Landmarks in Byzantine Philosophy], The Publishing House of Axis Foundation, Iaşi, 2003, p.163.

${ }^{4}$ L. Uspensky, Teologia icoanei [The Theology of Icon], "Anastasia" Publishing House, 1994, p. 24.
} 


\section{The structural analysis of the icon}

Any type of human communication, implicitly divine-human can be studied as a semiotic situation, as an ensemble of factors which assure the elaboration and communication of specific information.

We will continue with the presentation of a structural analysis of the Orthodox Church, following the model of the semio-logical hexad which describes the creative communication situation ${ }^{5}$.

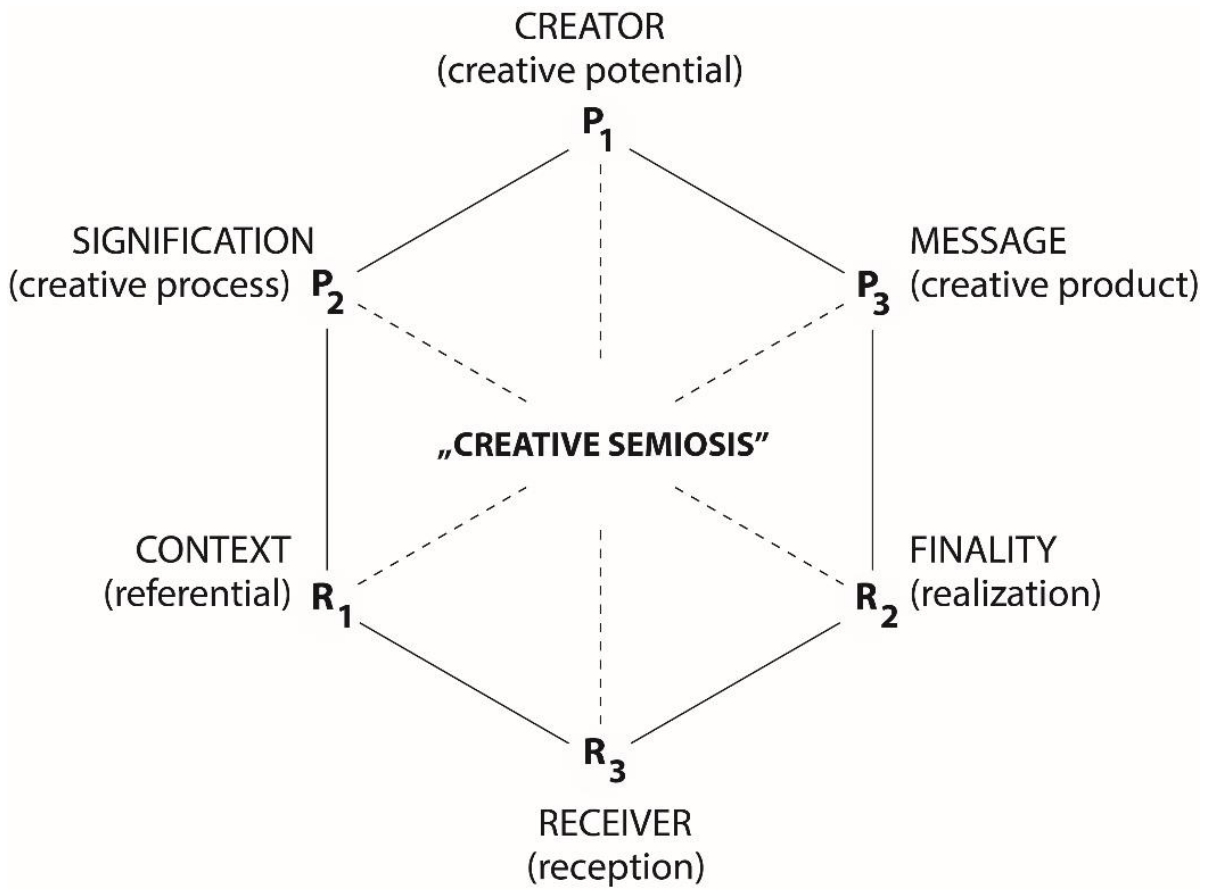

Fig.1 The hexadic model of the situation "creative communication"6

Starting with the presentation of the socio-cultural context in which the icon appears (R1) and continuing with the other parameters of the hexad - the purpose which justifies the triggering of the creative act (R2), to whom the mirror is addressed (R3), who creates it (P1) and what psycho-logical mechanisms have led to its birth (P2), which the result of this creative

\footnotetext{
${ }^{5}$ Traian D. Stănciulescu, La început a fost semnul [At the beginning, it was the sign], "Performantica" Publishing House, Iaşi, 2004.

${ }^{6}$ Traian D. Stănciulescu, Introducere în filosofia creației umane [Introduction in the Philosophy of Huma Creation], Junimea Publishing House, 2005, p.19.
} 
process is, the transmitted message $(\mathrm{P} 3)$ - we have focused ourselves on the defining and description of what the icon is.

Context. Placing ourselves in the moment when the icon appeared as an element of novelty in the history of arts, we realize it cannot be reduced to the category "work of art". Only by looking at the disputes which have taken place over centuries, we realize that by regarding it as a work of art and that is all, we deprive them of its defining meaning.

The new culture (Byzantium) which gives birth to the icon is a synthesis of the Greek, Roman and Christian cultures, but not only. And maybe it is difficult to show to what extent each nation with an old culture which was part of the Byzantine Empire, for example the Judeans or the Syrians, has contributed to the shaping of this new culture.

Christianity is based on Judaism, being a continuation and a fulfillment of it. This is the reason why many of the problems that have troubled Christianity have their origins in Judaism. Its refusal of any representation of the divinity is explained by the law transmitted by Moses: "You shall not make graven image and no type of resemblance to anything from the sky, up, and what it is on earth, down and what it is in the waters underneath the earth!'(Escape 20,4). But, the cherubs from the Ark of the Covenant do not constitute any breaking of the law, having been modelled according to the will of God (Escape 25, 18-22).

Regarding the Greeks, their position about the image is totally different, even if there were philosophers who claimed they were against the representations of gods and goddesses. The portrait of the sovereign was adored by the citizens, this thing was later taken over by the Romans. Spread up to the borders of the empire, the portrait had a judicial value, being the equivalent of the presence itself.

Still, there are theories which claim that "Christian art was born outside the Church". Step by step, it "accepted it, imposing it some rules, but Christian art was actually born from the initiative of the believers"" .

We can we say that Christian art was born in catacombs. But in what way has this been done? There are numerous pagan symbols taken by the Christians from the primary Church and transformed to express the knowledge of the Church. At the beginning, Christian art used the forms of ancient art, adding a new content (the fish - symbol of fecundity and then of eroticism, becomes in Christianity the abridged formula of the Creed - IHTIS in Greek, it is the short form of "Iisus Hristos Theou Uios Sotir - Jesus Christ, the Son of God, our Saviour"; the peacock, the dove, the palm tree become foreshadowings of Heaven etc.). But they are not only taken, but also new symbols are invented. This symbolic language is explained first of all by

\footnotetext{
${ }^{7}$ L. Bréhier, L'Art Crétien [Christian Art], Paris, 1928, pp.13 and 16.
} 
the need to express a reality which can not be explained without mediation. Biblical images were used, for example the lamb, the fish, the ark etc.

Especially in the $2^{\text {nd }}$ century, new symbols are invented: the worship of the magi is connected to the convertion of the pagans to faith, the multiplication of loaves - to the Last Supper, the grape wine - to the sacrament of divine life to the ones that are baptised etc.

The purpose. On the one hand, the role of this art, of this painting language which was step by step configured was a didactic one, that is to keep the flame of the faithful neophytes alive. On the other hand, through images was formed a secret code step by step revealed to the catechumens, in a pagan world, hostile to Christianity.

The Church has slowly attributed to the image, implicitly to the icon, a great importance, not only because of its lecturing function, but also because of its Liturgical function, of worshiping God through all the created things. Thus, the icon has become an essential, fundamental element of the public divine cult that it embelished with its silent and intimate mightiness. Everything that is promoted through word is strengthened through the images which become a proof.

Because the Church has always strived for orienting the entire human senses towards the knowledge and worship of God, it was utterly important to direct the sense of sight towards God.

The icon helps the believer focus on prayer, it facilitates the connection, the communication with the One Who is represented. It is the support for meditation, the seen representations lead towards the contemplation of what is unseen. The lack of realism, the lack of conformity with nature remind us that the body is from now on more oriented towards the spiritual world. The refusal of naturalism in the representation of organsunderlines the detachment from the noise of the world, in order to perceive the spiritual world. What is the most important regarding the icon is the fact that it asks for a personal relationship between the viewer and the represented person (or people).

The icon is the proof that we are not alone - "I will be with you until the end of all times". The Christian has the conscience that one takes part at the great family of saints. It is enough to contemplate the painted interior of churches in order not to feel alone. Every prayer is communication with God and His saints, with the victorious Church that they form. In this respect, the iconostasis is not a barrier between the priest and the believers, but it is "the maximum expression of what can manifest itself visually, because behind it, there is nothing to be seen, meaning that the sacrament which takes place there is not in the sphere of the visible, but of the communion". ${ }^{8}$ Besides making a recap of the history of deliverance, it also suggests the passing

\footnotetext{
${ }^{8}$ Ibidem, p. 37.
} 
through another world, not seen by bodily eyes, it is the border between the world of senses and the world of spirit.

By icon, the Holy Spirit of God is transmitted to the believers. This is the reason why negating the icon, in the space of the Church, is the equilavalent of denying the Holy Spirit. Thus, we can even say that it has a therapeutic role, of offering spiritual healing, first of all, mental one and even bodily one, exactly through the Holy Spirit which it transmits.

The icon answers the deep psychological need of representation in order to have a harmonious life. Both in the Old Testament and in the New Testament, it is heard the man's desire to see God: "God, show us the father and it will be enough for us!" At this request addressed by the Saint Apostle Philip at the Last Supper, the Saviour replies: "I have been with you for so long, Philip, and you still haven't recognised Me? The one who saw Me saw the Father; and how come you ask: <Show us the Father!?> Don't you believe that I am inside the Father and the Father is inside Me?" (John 14, 8$10)$.

Moreover, the icon also has an anamnestic role, to remind us that God is present everywhere and permanently. This is the reason why the icon is always present in the Church, to visibly signal God who is not visible for our bodily eyes.

Through the icon, the aesthetic sense is educated. "Beauty will save the world", said Dostoevsky. The man is thirsty for beauty, and Paul Evdokimov considered that "if the man is searching for beauty, this is possible because he is bathed in its light, because in the man's nature itself, the man is thirsty, yearning for its light, because in man's deep nature, one is thirsty for Beauty and His face". In the absence of this Beauty, the world loses its meaninf. The thought of every icon maker is precisely the creation of this Beauty.

The receiver. As we have seen, the icon is addressed to all believers, and also to the ones who have not got acquainted with the Christian faith. This happens because the icon preaches the Word of God to all people, no matter their faith. The icon has the capacity of transmitting its message to every human being who is searching for God. We have met people who have become Christian Orthodox being impressed by the beauty of icons. And not only the artistic beauty was the one that impressed them, but the Presence that the icon made perceivable.

Means. As far as the practic realization of an icon is made, it has always been done according to some rules, in many cases unwritten, but which have not been strictly respected, being transmitted from master to apprentice. In time, they have become a code a laws or principles that can guide the ones that want to transmit the Truth of faith through the icon.

If, initially, the necessity of some rules was not felt (and also regarding artistic realization), they have proven their necessity once some 
heretic practices appeared in which the icon was involved. Coming to be worshipped as an object itself, not as a sign of the unseen by some Christian fractions, the icon was the object of some of the bitterest theological debates in the history of Christianity - the dispute between iconoclasts and iconophils.

At the ecumenic Synod 7 from 787 from Niceea, through the disputes connected to the legitimacy of representing the Son of God, deep aspects were made clear, regarding the dogma of the Embodiment and the way in which the faithful should perceive the icon, so that exaggerations are avoided, for example the one that made the icon, a cult object, become the object of disunion inside the Church. Thus, it was established that the icon be worshiped just like the Holy cross, meaning by kissing, being placed in a honorable place inside the church to be worshiped, because this worship is directed towards the prototype. Having brought these clarifications and other, also brought by Saint John of Damascus in The Three Treaties against the Iconoclasts, it was put an end to the split which existed in the Church on this topic.

In cultural environments, there is the tendency of looking at the icon just like an aesthetic object and belonging to the heritage, thus abolishing its defining quality, the one of sacred object through which it is transmitted the divine revelation

The emitter. Who creates the icon? The painter? The theologian? The Holy Spirit through both of them?

It existed and it still is the position according to which the painter is just a tool through which the grace of God works. According to this opinion, the man borrows the hands and eyes of God in order to paint the icon, and the personal contribution of the man would be "the good will".

Still, man has been created according to the face of God and it is asked to resemble the prototype. Does not this resemblance involve the capacity to create? Yes, of course, yes! But, one does not have the capacity to create out of nothing, but by using matter/ the things created by God. But, in order to have the ability to create, it is not enough the fact that the man was created according to the face of God, but he, the painter, must have the tendency to resemble God as much as possible. From this moment on, he truly starts to be a creator, if one has, of course, the artistic knowledge and the skill necessary for such an action. Given these aspects, at the beginning, the painters of icons are asked to respect the existent models and they are not allowed to experiment new representations. Despite all these, the road towards creative innovations regarding icon representations is not closed yet. Thus, new models can always appear which are part of the already existent tradition, though they bring elements of novelty. An eloquent example in this respect is the icon of the Holy Trinity made by Andrei Rubliov. 
First of all, the icon maker had to "paint" one's own soul just like an icon, then one would be capable of painting that world unseen by us, but in which the painter is already living. Thus, new icons have appeared and they are not obviously different from the others regarding stylistic, artistic aspects, but they have that something which enters the heart of the one who looks at them, changing one's life. Maybe such a painter created the icon of the Virgin Mary, changing the life of the prostitute from Alexandria and determining her to become St. Mary from Egypt... Maybe such painters have created Hagia Sophia, which was seen by the emissaries of the Prince of Ukraine and who convinced him that they had found the place where God descends among people...

Art serving God can determine the artist to elevate himself at the state of servant of the grace of God. By answering the divine call, the painter becomes together worker with God at one's own salvation and of his fellows through the holy images that one paints as a fruit of this divine-human cowork.

The painter, before putting the icon on wood, gives birth to it inside his soul through prayer, serenity and ascesis. After having cleared his sight and through it, his heart, he reproduces the face of a transfigured world. One ought not to transmit through the icon one's emotional states which do not correspond to the spiritual reality of faith.

"The representation of God is a fearful task. [...] This is the reason why the Orthodox Church is very demanding regarding the painters who should conform to an ensemble of canons [...]. Defined canonically, the theme of the icon is not connected to the abilities of the artist. The same happens to its symbolism"9. The icon is not the result of individual thinking, but it is specific to a synod of Orthodox thinking regarding the truth of faith and the holy sacraments of salvation which they reveal to us.

As a conclusion of what we have said so far, the icon cannot be painted only with God's grace and the human being's kindness, but, on the contrary, in the creative process, there are involved the moral and intellectul qualities the artist has not only talent as a gift from God, but also the inner drive to take them to perfection. This effort is, in most cases, a conscious actboth intellectually and practically, being always enriched (consciously or unconsciously) by a divine inspiration which makes the creative act have a final goal which does not depend on the imagination of the artist who has started the creation process. Thus, while the creative act takes place, the initial purposes can be modified and can even become secondary. The spiritual being of the painter are transformed from subjective-creative values into objective-created values.

\footnotetext{
${ }^{9}$ Ibidem, p. 46.
} 
The connection between image, which is the type and the represented person, the prototype, is the resemblance and the fact that they have the same name. Because of these two characteristics, the icon is saint, according to what the Patriarch Nichifor wrote in his treaty against the iconoclasts from the $8^{\text {th }}$ century.

Content. In order to have an authentic relationship between God and the human being, it is necessary the real presence of the two persons that constitute the terms of this relationship. According to the wisdom of the Holy Bible, the human being has been created to rejoice with God. The divine presence offers the human being the true spiritual verticality. The moment when the human being turns one's face away from God, one will fall. The presence of the Face of God before the human being is necessary, even to the accomplished ones.

To always see God before you is the condition of maintaining spiritual ascension, just like the Psalmist David says: "I have seen God before me, for on my right is not to shake". (Ps. 15, 8)

The universe that the icon shows us is the one in which the divine grace rules, not rational categories or human morals. In it, there are also encapsulated the effort of ascesis and the joy of victory. As an expression of the revealable truth, the icon confesses the salvation "prepared beforehand to all peoples". It reveals the large vision which unites past and future in a continuous present through which the secret of the world to come is revealed.

The future transfiguration of the entire human nature is foretold by Christ's Transfiguration on Mount Tabor. The entire body of Christ is transfigured, thus becoming, we dare say, the full of light cloth of His divinity. In this way, the bodies of the saints are worshipped and become light, being transformed through the power of the divine grace. They accomplish the main goal of existence by dressing up in the undying beauty of the Kingdom of God.

The human being has been created according to the Face of God and one is called to resemble One's Creator. This is the message of the icon. Beauty is not the beauty specific to the present phase of creation, but an attribute of the century which is to come. The value and beauty of the seen world do not consist in the ephemeral splendour of its present phase, but in its potential transfiguration, made with the help of the human being.

The icon thus transmits the divine beauty and praise with material means, visible to bodily eyes. The Church Fathers say that the icon is honorable and saint just because it transmits the godly condition of its prototype and it bears its name, this is the reason why the grace specific to the prototype can be found in it. The gift of the Holy Spirit is the one that awakens holiness both in the represented person and in one's icon, and in 
Him is the relation between a believer and a saint, through the saint's mediation.

The harmony of the human body is correlated with the cosmic harmony and it is a source of beauty. It is harmony beyond time and space. "The icon is painted in a specific amount of time, but it calls the believer beyond time." 10

Instead of conclusions. Everything that is seen (visible) is under the sign of endowment. The enire world is created by God as a gift for people, life itself is a gift. Everything that we eat or drink "after having worked"(Eccl. 3, 13), wisdom, science, joy are gifts of God. ${ }^{11}$

A painting (the true painting, just like Jean-Luc Marion defines it) does not reproduce an existent visible, but it lets a totally new phenomenon manifest itself through it, no (longer) seen before which, because it does not immitate nature, completes the world. It is a ou, ne(mai)văzut care, pentru că nu imită natura, completează lumea. It is a no (longer) seen which gives itself to the visible through the intermediation of the painter, without the artist's help, it would have rested forever not-visible, therefore not endowed. It "is caught by neither the one who painted it, nor the one who looks at it". It appears through the eyes of the painter or the viewers, but it precedes them and determines them, it does not obey them. ${ }^{12}$.

The painting offers itself, but the painting act limits itself to receiving, recording and framing an endowment on a support. Therefore, painting means waiting for an endowment. After this, in order to see [...] what is offered by the one which offers, we must make ourselves capable of offering." ${ }^{13}$ The complete dialogue of the gift consists in receiving and returning the gift, through this, the receiver truly enriches oneself. In the present case, both the viwer and the painter are receivers; the difference between them consists in the fact that the painter is in the same time a coofferer with the unseen through one's diligence and skill. Through the act of painting, the painter also receives and returns the gift, thus completing the dialogue. The viewer can return the gift by worshipping it because "every gift asks to be received" 14 and a gift is appreciated because before it is offered, it is subjected to critic analysis.

\footnotetext{
${ }^{10}$ Dan Belu, Iconografia ca izvor omiletic [Iconography as a Homiletic Symbol], in M.A., Sibiu, anul III, nr.11-12, 1958, p.878.

${ }^{11}$ Pr. Prof. Dr. Dumitru Stăniloae, Teologia Dogmatică Ortodoxă [Orthodox Dogmatic Theology], vol. I, The Publishing House of the Biblical Institute and of Mission of the Romanian Orthodox Church, Bucharest, 1996, p. 234.

${ }^{12}$ Jean-Luc Marion, Crucea vizibilului [The Cross of the Invisible], Deisis Publishing House, Sibiu, 2000, p. 64.

${ }_{13}^{13}$ Ibidem, p. 74.

${ }^{14}$ Ibidem, p. 75.
} 
The icon is a kenosis of the image in order to let appear in it "the track of the invisible that looks straight into our eyes" ${ }^{\prime 15}$. According to her prototype, the icon cleans itself out of image, of any illusion in order to make the look of the Invisible possible to be seen. It empties oneself of every praise, and the worship that it allows to take place towards its prototype does not keep it only for itself.

Somehow, the icon makes Jesus Christ Himself transparent, and through this, even God the Father becomes transparent (because "who has seen Me, has seen my Father") because it gives us the consciousness of His own presence with His own face before us, in an invisible environment.

By looking at His icon, the believer is challenged in a special and pressing way to think about Christ and to address Him prayer words, just like our neighbour challenges us to address her/him, or our face extremely powerfully presses the one that we address to answer us. And our presence which is addressed to God before His icon makes Him answer our words. ${ }^{16}$

God himself gives Himself to the human being through the icon, in the dialogue which one facilitates and thus, the icon becomes a double offering.

\section{Bibliography:}

Belu, Dan - Iconografia ca izvor omiletic [Iconography as a Homiletic Spring], in Mitropoly of Ardeal, Sibiu, year III, no.11-12, 1958.

Branişte, E - Programul iconografic al Bisericii Ortodoxe - Indrumar pentru zugravii de biserici [The Iconographic Program of the Orthodox Church - Guideline for Church Painters], Bucharest, 1979.

Chiţoiu, Dan - Repere în filosofia bizantină [Landmarks in Byzantyne Philosophy], The Publishing House of Axis Foundation, Iaşi, 2003.

Marion, Jean-Luc - Crucea vizibilului [The Cross of the Visible], Deisis Publishing House, Sibiu, 2000.

Stănciulescu, Traian D. - Introducere în filosofia creației umane [Introduction in the Philosophy of Human Creation], Junimea Publishing House, Iaşi, 2005.

Stănciulescu, Traian D. - La început a fost semnul. O altă introducere în semiotică [At the Beginning, it was the Sign. Another introduction in Semiotics], Performantica Publishing House, Iaşi, 2004.

Stăniloae, Dumitru, Priest, Professor, PhD - Icons in the Orthodox Worship in ,"Orthodoxy", year XXX, 1978, no.3.

\footnotetext{
${ }^{15}$ Ibidem, p. 99.

${ }^{16}$ Dumitru Stăniloae, Priest, Professor, $\mathrm{PhD}$, Icoanele în cultul ortodox [Icons in the Orthodox Cult], in "Orthodoxy", year XXX, 1978, no.3.
} 
Stăniloae, Dumitru, Priest, Professor, PhD - Orthodox Dogmatic Theology, vol. I, The Publishing House of the Biblical Institute and of Mission of the Romanian Orthodox Church, Bucharest, 1996.

Uspensky, Leonid - Teologia icoanei [The Theology of Icon], Anastasia Publishing House, 1994. 